\title{
Influence of Elicitation and Germination Conditions on Biological Activity of Wheat Sprouts
}

\author{
Dariusz Dziki, ${ }^{1}$ Urszula Gawlik-Dziki, ${ }^{2}$ \\ Monika Kordowska-Wiater, ${ }^{3}$ and Monika Domań-Pytka ${ }^{3}$ \\ ${ }^{1}$ Department of Thermal Technology, University of Life Sciences, Doświadczalna Street 44, 20-280 Lublin, Poland \\ ${ }^{2}$ Department of Biochemistry and Food Chemistry, University of Life Sciences, Skromna Street 8, 20-704 Lublin, Poland \\ ${ }^{3}$ Department of Biotechnology, Human Nutrition and Science of Food Commodities, University of Life Sciences, \\ Skromna Street 8, 20-704 Lublin, Poland
}

Correspondence should be addressed to Urszula Gawlik-Dziki; urszula.gawlik@up.lublin.pl

Received 29 November 2014; Revised 29 January 2015; Accepted 30 January 2015

Academic Editor: Iciar Astiasaran

Copyright (C) 2015 Dariusz Dziki et al. This is an open access article distributed under the Creative Commons Attribution License, which permits unrestricted use, distribution, and reproduction in any medium, provided the original work is properly cited.

\begin{abstract}
The influence of elicitation, time, and temperature of germination on the biological activity of wheat sprouts was studied. The total phenolics content (TPC), antioxidant activity (AA), and microbiological purity of seeds of three wheat cultivars elicited with Saccharomyces cerevisiae (Y) and Salix daphnoides bark extracts (W) and their mixture (1:1) germinated in different conditions were studied. The increase of germination time caused an increase the TPC and AA for all tested wheat cultivars. Germination temperature also influenced these parameters. Generally the highest values in TPC were obtained for sprouts germinated at $20^{\circ} \mathrm{C}$. This tendency was found for all tested wheat cultivars. The highest values of TPC and AA were obtained after elicitation by $S$. daphnoides bark extract. The results of microbiological examination showed that generally for seeds germinated at lower temperature $\left(15^{\circ} \mathrm{C}\right.$ and $\left.20^{\circ} \mathrm{C}\right)$ and during 2 and 4 days the molds were not detected and the levels of aerobic bacteria did not exceed the usually accepted limits. Taking into account both biological activity and microbiological purity of samples the best quality sprouts were in the most cases obtained for wheat germinated during four days at $20^{\circ} \mathrm{C}$ and elicited by W.
\end{abstract}

\section{Introduction}

Wheat (Triticum aestivum) is one of the major world agricultural products, with a total global production of about 600 700 million tons and provides $20 \%$ of the daily protein and food calories for 4.5 billion people $[1,2]$. Wheat is by far the most important crop for bread making because of its supreme baking performance in comparison with all other cereals. Especially wholemeal wheat flour contains high amount of nutrients such as dietary fiber, starch, vitamins, minerals, and phytochemicals, which not only take part in construction of body tissues but also help to reduce a risk of many health problems [3]. Some of these nutrients are reported to increase during sprouting $[4,5]$. Seed viability and vigor are important aspects of seed quality and important in determining the success of a planted crop. During sprouting, some seed reserves are degraded and used for respiration and synthesis of new cell constituents for the developing embryo, thereby causing significant changes in the biochemical, nutritional, and sensory characteristics of the cereal [6]. Germination of seeds has been shown to be a successful strategy to increase the content of antioxidant compounds such as phenolic compounds that present free radical scavenging activity [4]. An interesting future trend can be the supplementation of wheat bread in flour from sprouted cereals and pseudocereals [7]. Wheat germination also increases the activities of the enzymes $\alpha$-amylase and various proteases which result in the degradation of both starch and protein. These changes adversely affect the baking quality of wheat [8]. The high amylolytic and proteolytic activity will not allow producing good quality bread from sprouted flour. However the acceptable bread from sprouted flour could be produced by lowering the $\mathrm{pH}$ and adding $4 \%$ vital gluten to the flour and using the "Short Time Fermentation Method" [9]. Besides, the dehydrated sprouted wheat flour can be used for making many of valuable for health products, such as noodles, pasta, 
laddu, unleavened bread, porridge, and gruels for newborns [10].

Due to the lack of public acceptance of transgenic food, elicitation has recently become a popular way not only to enhance the resistance of plants to biotic and abiotic stresses, but also to improve the quality of edible plants, especially in relation to their health-promoting phytochemicals. Genetic manipulation of food is controversial. Modification of chemical composition and bioactivities of plant food by elicitors is cheaper and socially acceptable. Several authors have applied exogenous elicitors during germination of seeds to stimulate seedling vigor and, in response, the biosynthesis of bioactive compounds, thereby contributing to a significant step toward disease prevention. Limón et al. [11] found that kidney beans elicited by glutamic acid led to the highest soluble phenolic compounds. Świeca et al. [12] showed that elicitation of lentil seeds during germination allowed for a significant enhancement of the antioxidant potential of sprouts. The highest increase in the antioxidant capacity was found for the sprouts obtained with phenylalanine and combined UV-tyrosine treatments. Burguieres et al. [13] found that the addition of vitamin $\mathrm{C}$ and folic acid during pea germination stimulated seed seedling vigor and increased its phenolics content and antioxidant activity. Gawlik-Dziki et al. [14] elicited broccoli seed using the extracts of $S$. cerevisiae and S. daphnoides bark for improvement of nutraceutical value of broccoli sprouts. They found that elicitation significantly increased the antioxidant properties of sprouts. Pérez-Balibrea et al. [15] proved that elicitation of broccoli sprouts with salicylic acid solution increased the flavonoids and sinapic and ferulic acid derivatives levels.

The objective of this research was to investigate the influence of germination conditions on biological activity of wheat sprouts. We also investigated the effect of seed priming with natural elicitors of the nutraceutical value in wheat seedlings. Besides, the microbiological purity of sprouts was evaluated.

\section{Materials and Methods}

2.1. Material. Investigations were carried out on three Polish winter wheat cultivars (Triticum aestivum ssp. vulgare): Bogatka, Mulan, and Muszelka. The seeds came from the field experiment conducted in 2013 at experimental station belonging to the Lublin Agricultural Advisory Center in Końskowola. Before germination, seeds were sterilized in $1 \%(\mathrm{v} / \mathrm{v})$ sodium hypochlorite for $10 \mathrm{~min}$ and then drained and washed with distilled water until they reached a neutral $\mathrm{pH}$. The seeds were placed in distilled water (control, C) and in distilled water contained $0.1 \%(\mathrm{w} / \mathrm{v})$ of Saccharomyces cerevisiae $(\mathrm{Y})$ extract, $0.1 \%(\mathrm{v} / \mathrm{v})$ Salix daphnoides $(\mathrm{W})$ bark extract, and their combinations (W/Y 1:1) for $6 \mathrm{~h}$ at $25^{\circ} \mathrm{C}$.

Elicitors were prepared as follows. (1) Instant yeast $S$. cerevisiae $\mathrm{L}$. was dissolved in distilled water at concentration of $0.1 \%(w / v)$ and autoclaved. (2) Bark of S. daphnoides (obtained from ecological farm, Poland) was dried and extracted with boiling water at concentration of $0.1 \%(\mathrm{w} / \mathrm{v})$.

Seeds were germinated for $2,4,6$, and 8 days in a controlled incubator (ICH 256, Memmert, Düsseldorf, Germany). Germination was carried out at 15,20 and $25^{\circ} \mathrm{C}$ in darkness. Sprouts were dried at $60^{\circ} \mathrm{C}$ at to the moisture level $12 \%(\mathrm{wb})$ and pulverized in laboratory meal according to procedure described by Dziki and Laskowski [16]. $500 \mathrm{mg}$ of powdered sprouts samples were extracted with $5 \mathrm{~mL}$ of $\mathrm{MeOH}:$ water $(1: 1, \mathrm{v} / \mathrm{v})$ mixture. Samples were shaken during $30 \mathrm{~min}$ and centrifuged $(13000 \mathrm{~g}, 10 \mathrm{~min})$. The procedure was repeated two times. Collected supernatants were used for biochemical analysis.

2.2. ABTS Radicals Scavenging Ability. The experiments were performed using an improved ABTS decolorization assay [17]. $\mathrm{ABTS}^{+\bullet}$ was generated by the oxidation of ABTS with potassium persulfate. The ABTS radical cation $\left(\mathrm{ABTS}^{+\bullet}\right)$ was produced by reacting $7 \mathrm{mmol} / \mathrm{L}$ stock solution of ABTS with $2.45 \mathrm{mmol} / \mathrm{L}$ potassium persulfate (final concentration). The $\mathrm{ABTS}^{+\bullet}$ solution was diluted (with distilled water) to an absorbance of $0.7 \pm 0.05$ at $734 \mathrm{~nm}$. Then, $40 \mu \mathrm{L}$ of samples were added to $1.8 \mathrm{~mL}$ of $\mathrm{ABTS}^{+\bullet}$ solution and the absorbance was measured at the end time of $5 \mathrm{~min}$. The ability of the extracts to quench the ABTS free radical was determined using the following equation:

$$
\text { scavenging } \%=\left[\frac{\left(\mathrm{A}_{\mathrm{C}}-\mathrm{A}_{\mathrm{A}}\right)}{\mathrm{A}_{\mathrm{C}}}\right] \times 100,
$$

where $A_{C}$ is absorbance of control and $A_{A}$ is absorbance of sample.

\subsection{Total Phenolics Estimation Total Phenolics Estimation.}

Total phenols were estimated according to the FolinCiocalteau method [18]. A $0.1 \mathrm{~mL}$ sample of the extract was mixed with $0.1 \mathrm{~mL}$ of $\mathrm{H}_{2} \mathrm{O}$, with $0.4 \mathrm{~mL}$ of Folin reagent $\left(1: 5 \mathrm{H}_{2} \mathrm{O}\right)$, and after $3 \mathrm{~min}$ with $2 \mathrm{~mL}$ of $10 \% \mathrm{Na}_{2} \mathrm{CO}_{3}$. After $30 \mathrm{~min}$, the absorbance of mixed samples was measured at a wavelength of $720 \mathrm{~nm}$. The amount of total phenolics was expressed as gallic acid equivalents (GAE).

2.4. Microbiological Examination. Sprouts were subjected to microbiological analysis in which the number of aerobic microorganisms, the number of yeast and molds, the total coliform, and the identification of Salmonella spp. were determined in accordance with the standards PN-EN ISO 4833 [19], PN-ISO 21527-2 [20], PN-ISO 4832:2007 [21], and PN-EN-ISO 6579:2003 [22], respectively.

2.5. Statistical Analyses. All experimental results were mean \pm SD of three parallel experiments. The obtained data was subjected to a statistical analysis and the consequent evaluations were analyzed for a variance analysis. The statistical differences were estimated through Tukey's test. Nonlinear regression analysis was also carried out on this data. Statistical tests were evaluated by using the Statistica 6.0 software (StatSoft, Inc., Tulsa, USA). All the statistical tests were carried out at a significance level of $\alpha=0.05$.

\section{Results and Discussion}

Sprouting is a complex process during which the seed must quickly recover physically from maturation drying, resume 

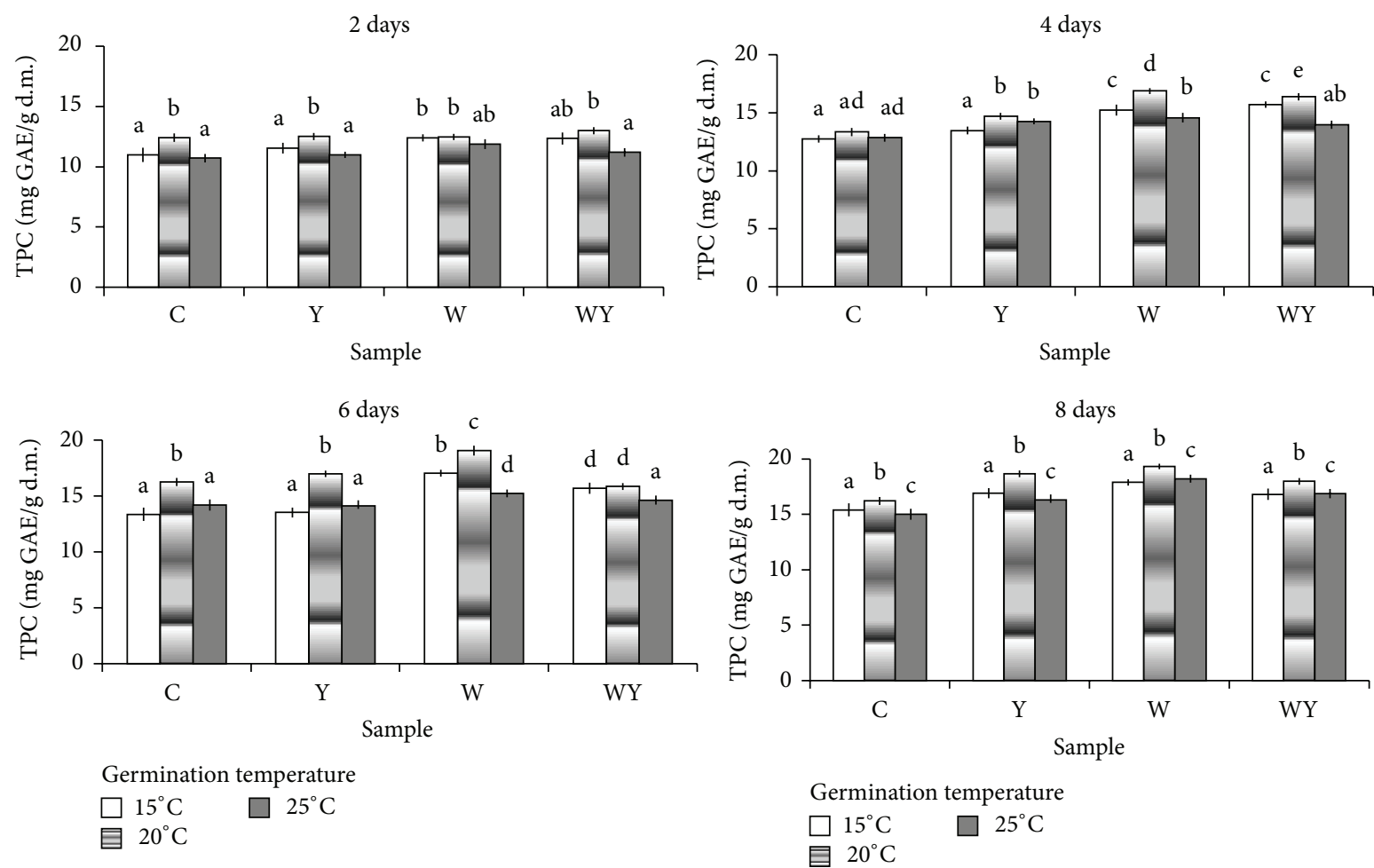

FIGURE 1: Total phenolics content in control and elicited sprouts depending on time of germination and germination temperature (cv. Bogatka); the values designated by the different letters for individual days of sprouting are significantly different $(\alpha=0.05)$; C represents control sprouts, Y represents sprouts elicited by yeast, W represents sprouts elicited by willow, and WY represents sprouts elicited by willow/yeast mixture.

a sustained intensity of metabolism, complete essential cellular events to allow for the embryo to emerge, and prepare for subsequent seedling growth [23]. From the other hand, sprouting may be regarded as a natural bioreactor or biotechnological module and could be used to improve the nutrition value in food products [24].

The results of total phenolics content (TPC) for sprouts obtained from individual wheat varieties are presented in Figures 1-3. Plant phenolics have potential health benefits mainly due to their antioxidant properties such as reactive oxygen species scavenging and inhibition, free radicals scavenging, and metal chelation [25]. The lowest values of TPC were obtained for wheat grain before germination (averages 10.67, 11.16, and $12.08 \mathrm{mg} \mathrm{GAE} / \mathrm{g}$ d.m. for Bogatka, Mulan, and Muszelka, resp.). The increase of germination time caused an increase the TPC. This tendency was observed for sprouts obtained from all cultivars. However the values of TPC obtained after 2 days germination were comparable with the values obtained for grain before germination. The highest values of TPC were found in sprouts germinated for 8 days (averages 17.1, 15.6, and $16.8 \mathrm{mg}$ GAE/g d.m. for Bogatka, Mulan, and Muszelka, resp.). Germination temperature slightly influenced TPC. Generally the highest values in TPC were obtained for sprouts germinated at $20^{\circ} \mathrm{C}$.

Seed and seedlings treatments for improving plant vigour are being developed and used. Increasingly, commercial seed treatment approaches are beginning to view seed treatments as a means to increase substantially the value of the seed and to improve plant growth and productivity [26]. The result showed that wheat seed elicitation by yeast had little or no significant influence on TPC, whereas willow bark extract and mixture on willow bark with yeast caused slight but significant increase in TPC. This tendency was observed for sprouts obtained from all cultivars. The average value of TPC for sprouts without elicitation was $13.3 \mathrm{mg}$ GAE/g d.m., whereas for elicited seeds the values of TPC were slightly higher, 13.9, 15.1, and 14.6 mg GAE/g d.m. for seeds elicited by yeast, bark, and their mixture, respectively. However the values of TPC obtained for wheat elicited by bark extract were in the most cases significantly higher from the control sample. The lowest values of TPC were obtained for sprouts obtained from Mulan cv. (average $14.1 \mathrm{mg} \mathrm{GAE} / \mathrm{g} \mathrm{d.m.)} \mathrm{and} \mathrm{the} \mathrm{highest}$ for Bogatka (average $14.7 \mathrm{mg}$ GAE/g d.m.).

During germination, the content and bioactivity of compounds with nutraceutical potential change dramatically and may be strongly affected by the germination conditions. Yang et al. [27] studied germination time and conditions for wheat grain to determine the optimum conditions that would maximize the production of antioxidants. These suggested that wheat grains germinated for 7 days at $16.5^{\circ} \mathrm{C}$ produced the most desirable sprouts with respect to antioxidant concentrations. However they did not study the microbiological purity of sprouts. Burguieres et al. [13] found that during wheat germination, Syringic acid levels rose as the length 

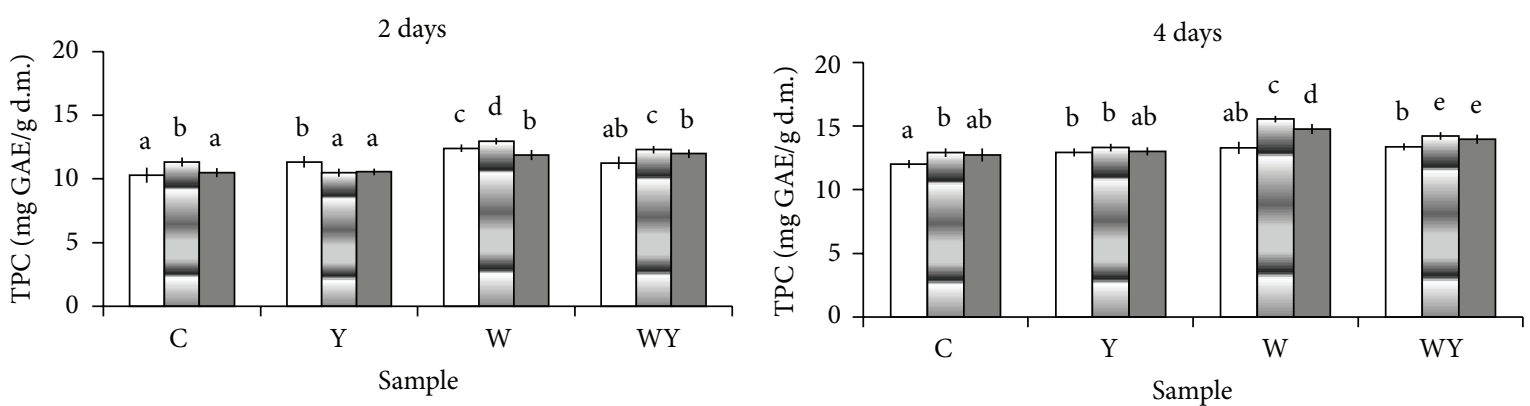

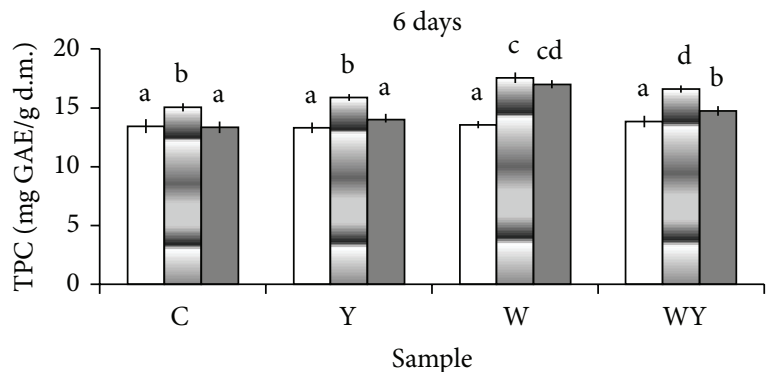

Germination temperature

$\square 15^{\circ} \mathrm{C} \quad \square 25^{\circ} \mathrm{C}$

目 $20^{\circ} \mathrm{C}$

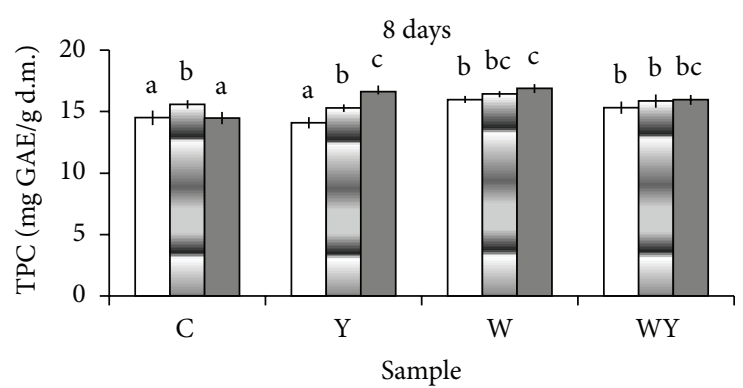

Germination temperature $\square 15^{\circ} \mathrm{C} \quad \square 25^{\circ} \mathrm{C}$ 目 $20^{\circ} \mathrm{C}$

FIGURE 2: Total phenolics content in control and elicited sprouts depending on time of germination and germination temperature (cv. Mulan); the values designated by the different letters for individual days of sprouting are significantly different $(\alpha=0.05)$; C represents control sprouts, Y represents sprouts elicited by yeast, W represents sprouts elicited by willow, and WY represents sprouts elicited by willow/yeast mixture.
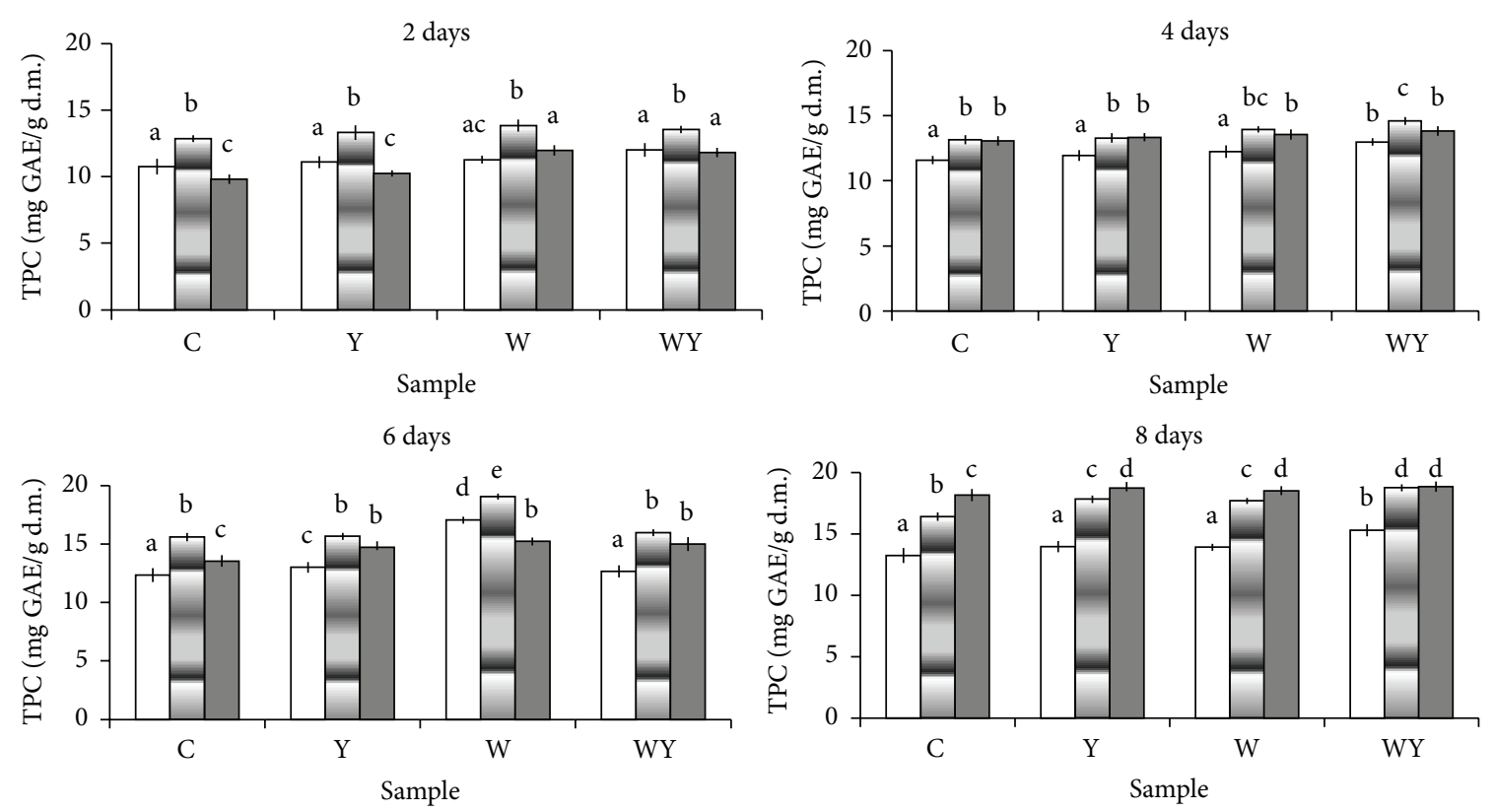

Germination temperature

Germination temperature
$\square 15^{\circ} \mathrm{C}$
$\square 25^{\circ} \mathrm{C}$
目 $20^{\circ} \mathrm{C}$
$\square 15^{\circ} \mathrm{C} \quad 25^{\circ} \mathrm{C}$
目 $20^{\circ} \mathrm{C}$

FIgure 3: Total phenolics content in control and elicited sprouts depending on time of germination and germination temperature (cv. Muszelka); the values designated by the different letters for individual days of sprouting are significantly different $(\alpha=0.05)$; C represents control sprouts, Y represents sprouts elicited by yeast, W represents sprouts elicited by willow, and WY represents sprouts elicited by willow/yeast mixture. 
TABLE 1: Antioxidant activity [\%] of control and elicited wheat spouts in relation to germination temperature and germination time.

\begin{tabular}{|c|c|c|c|c|c|c|}
\hline \multirow{2}{*}{ Cultivar } & \multirow{2}{*}{ Sample } & \multirow{2}{*}{ Germination temperature $\left[{ }^{\circ} \mathrm{C}\right]$} & \multicolumn{4}{|c|}{ Germination time (days) } \\
\hline & & & 2 & 4 & 6 & 8 \\
\hline \multirow{12}{*}{ Bogatka } & \multirow{3}{*}{$\mathrm{C}^{*}$} & 15 & $8.5 \pm 0.34^{\mathrm{aA} * *}$ & $9.1 \pm 0.42^{\mathrm{aB}}$ & $11.3 \pm 0.68^{\mathrm{abC}}$ & $15.1 \pm 1.03^{\mathrm{bcD}}$ \\
\hline & & 20 & $8.6 \pm 0.42^{\mathrm{abA}}$ & $10.5 \pm 0.44^{\mathrm{bB}}$ & $11.6 \pm 0.66^{\mathrm{bcC}}$ & $14.5 \pm 0.66^{\mathrm{bD}}$ \\
\hline & & 25 & $8.7 \pm 0.55^{\mathrm{abA}}$ & $10.6 \pm 0.33^{\mathrm{bB}}$ & $10.8 \pm 0.38^{\mathrm{aB}}$ & $12.7 \pm 0.45^{\mathrm{aC}}$ \\
\hline & \multirow{3}{*}{$\mathrm{Y}$} & 15 & $9.0 \pm 0.31^{\mathrm{bA}}$ & $11.7 \pm 0.64^{\mathrm{cB}}$ & $12.5 \pm 0.72^{\mathrm{dB}}$ & $14.9 \pm 0.39^{\mathrm{bcC}}$ \\
\hline & & 20 & $9.2 \pm 0.18^{\mathrm{bA}}$ & $10.5 \pm 0.33^{\mathrm{bB}}$ & $11.3 \pm 0.68^{\mathrm{bB}}$ & $15.3 \pm 0.88^{\mathrm{cC}}$ \\
\hline & & 25 & $9.0 \pm 0.13^{\mathrm{bA}}$ & $9.2 \pm 0.51^{\mathrm{aA}}$ & $11.3 \pm 0.91^{\mathrm{bB}}$ & $12.9 \pm 0.92^{\mathrm{aC}}$ \\
\hline & \multirow{3}{*}{$\mathrm{W}$} & 15 & $11.9 \pm 0.28^{\mathrm{eA}}$ & $12.3 \pm 0.87^{\mathrm{cA}}$ & $14.2 \pm 0.42^{\mathrm{eB}}$ & $16.8 \pm 1.20^{\mathrm{dC}}$ \\
\hline & & 20 & $11.5 \pm 0.33^{\mathrm{eA}}$ & $13.6 \pm 0.92^{\mathrm{cB}}$ & $14.3 \pm 1.02^{\mathrm{eB}}$ & $17.3 \pm 0.94^{\mathrm{dC}}$ \\
\hline & & 25 & $9.9 \pm 0.34^{\mathrm{cA}}$ & $10.6 \pm 0.84^{\mathrm{bA}}$ & $12.6 \pm 0.53^{\mathrm{dB}}$ & $17.3 \pm 1.32^{\mathrm{dC}}$ \\
\hline & \multirow{3}{*}{ WY } & 15 & $10.8 \pm 0.41^{\mathrm{dA}}$ & $12.5 \pm 0.64^{\mathrm{cB}}$ & $13.1 \pm 0.74^{\mathrm{dB}}$ & $16.5 \pm 1.24^{\mathrm{dC}}$ \\
\hline & & 20 & $10.7 \pm 0.39^{\mathrm{dA}}$ & $12.6 \pm 0.38^{\mathrm{cB}}$ & $15.6 \pm 0.28^{\mathrm{eC}}$ & $16.5 \pm 0.97^{\mathrm{dC}}$ \\
\hline & & 25 & $9.6 \pm 0.11^{\mathrm{cA}}$ & $10.3 \pm 0.74^{\mathrm{bA}}$ & $12.0 \pm 0.39^{\mathrm{cdB}}$ & $14.4 \pm 1.12^{\mathrm{bC}}$ \\
\hline \multirow{12}{*}{ Mulan } & \multirow{3}{*}{$\mathrm{C}$} & 15 & $9.3 \pm 0.14^{\mathrm{aA}}$ & $11.7 \pm 0.25^{\mathrm{aB}}$ & $12.1 \pm 24^{\mathrm{aBC}}$ & $12.7 \pm 0.42^{\mathrm{aC}}$ \\
\hline & & 20 & $10.4 \pm 0.35^{\mathrm{bA}}$ & $12.6 \pm 0.14^{\mathrm{bcB}}$ & $14.4 \pm 0.31^{\mathrm{cC}}$ & $14.4 \pm 0.25^{\mathrm{bC}}$ \\
\hline & & 25 & $9.4 \pm 0.22^{\mathrm{aA}}$ & $12.0 \pm 0.54^{\mathrm{abB}}$ & $12.4 \pm 0.47^{\mathrm{aB}}$ & $13.7 \pm 0.45^{\mathrm{bcC}}$ \\
\hline & \multirow{3}{*}{$\mathrm{Y}$} & 15 & $10.1 \pm 0.31^{\mathrm{bA}}$ & $11.4 \pm 0.35^{\mathrm{aB}}$ & $12.3 \pm 28^{\mathrm{aC}}$ & $13.1 \pm 0.18^{\mathrm{cD}}$ \\
\hline & & 20 & $10.7 \pm 0.72^{\text {beA }}$ & $13.3 \pm 0.17^{\mathrm{ceB}}$ & $13.2 \pm 32^{\mathrm{bB}}$ & $13.4 \pm 0.11^{\mathrm{cB}}$ \\
\hline & & 25 & $10.2 \pm 0.63^{\mathrm{bA}}$ & $12.8 \pm 0.28^{\mathrm{cB}}$ & $13.4 \pm 22^{\mathrm{bdC}}$ & $13.6 \pm 0.28^{\mathrm{cdC}}$ \\
\hline & \multirow{3}{*}{ W } & 15 & $11.9 \pm 0.81^{\mathrm{cA}}$ & $12.4 \pm 0.47^{\mathrm{bcA}}$ & $13.9 \pm 0.45^{\mathrm{cdB}}$ & $14.1 \pm 0.43^{\mathrm{bdB}}$ \\
\hline & & 20 & $12.9 \pm 0.96^{\mathrm{dA}}$ & $14.3 \pm 0.32^{\mathrm{dB}}$ & $15.8 \pm 0.43^{\mathrm{eC}}$ & $16.6 \pm 0.45^{\mathrm{eD}}$ \\
\hline & & 25 & $12.1 \pm 1.05^{\mathrm{dA}}$ & $14.2 \pm 0.23^{\mathrm{dB}}$ & $15.4 \pm 38^{\mathrm{eC}}$ & $16.8 \pm 0.56^{\mathrm{eD}}$ \\
\hline & \multirow{3}{*}{ WY } & 15 & $11.3 \pm 0.77^{\mathrm{efA}}$ & $12.8 \pm 0.35^{\mathrm{bcB}}$ & $13.6 \pm 0.48^{\mathrm{bdB}}$ & $14.8 \pm 0.51^{\mathrm{bC}}$ \\
\hline & & 20 & $11.8 \pm 0.55^{\mathrm{fA}}$ & $14.6 \pm 0.56^{\mathrm{dB}}$ & $14.9 \pm 0.52^{\mathrm{eB}}$ & $16.9 \pm 0.62^{\mathrm{eC}}$ \\
\hline & & 25 & $11.6 \pm 0.56^{\mathrm{fA}}$ & $13.6 \pm 0.48^{\mathrm{eB}}$ & $14.6 \pm 0.21^{\mathrm{cC}}$ & $16.4 \pm 0.48^{\mathrm{eD}}$ \\
\hline \multirow{12}{*}{ Muszelka } & \multirow{3}{*}{$\mathrm{C}$} & 15 & $8.5 \pm 0.44^{\mathrm{aA}}$ & $10.3 \pm 0.39^{\mathrm{aB}}$ & $11.3 \pm 0.33^{\mathrm{aC}}$ & $11.9 \pm 0.18^{\mathrm{aC}}$ \\
\hline & & 20 & $11.7 \pm 0.58^{\mathrm{dA}}$ & $11.4 \pm 0.13^{\mathrm{bB}}$ & $12.2 \pm 0.21^{\mathrm{bB}}$ & $14.8 \pm 0.33^{\mathrm{dC}}$ \\
\hline & & 25 & $8.8 \pm 0.31^{\mathrm{abA}}$ & $12.9 \pm 0.33^{\mathrm{dB}}$ & $13.4 \pm 0.37^{\mathrm{cB}}$ & $16.4 \pm 0.42^{\mathrm{fC}}$ \\
\hline & \multirow{3}{*}{$\mathrm{Y}$} & 15 & $9.2 \pm 0.54^{\mathrm{abA}}$ & $11.6 \pm 0.14^{\mathrm{bB}}$ & $12.2 \pm 0.39^{\mathrm{bC}}$ & $12.7 \pm 0.44^{\mathrm{bC}}$ \\
\hline & & 20 & $11.9 \pm 0.28^{\mathrm{dA}}$ & $12.0 \pm 0.52^{\mathrm{bcA}}$ & $13.6 \pm 0.32^{\mathrm{cB}}$ & $15.5 \pm 0.31^{\mathrm{eC}}$ \\
\hline & & 25 & $10.2 \pm 33^{\mathrm{cA}}$ & $12.0 \pm 0.32^{\mathrm{cB}}$ & $13.2 \pm 0.28^{\mathrm{cC}}$ & $13.8 \pm 0.42^{\mathrm{cC}}$ \\
\hline & \multirow{3}{*}{$\mathrm{W}$} & 15 & $11.5 \pm 0.41^{\mathrm{deA}}$ & $13.0 \pm 0.18^{\mathrm{dB}}$ & $14.5 \pm 0.47^{\mathrm{deC}}$ & $15.0 \pm 0.43^{\mathrm{eD}}$ \\
\hline & & 20 & $12.7 \pm 0.48^{\mathrm{fA}}$ & $13.7 \pm 0.25^{\mathrm{dB}}$ & $13.9 \pm 0.38^{\mathrm{dB}}$ & $16.6 \pm 0.28^{\mathrm{fC}}$ \\
\hline & & 25 & $12.4 \pm 0.98^{\mathrm{fA}}$ & $13.6 \pm 0.33^{\mathrm{dB}}$ & $14.4 \pm 0.35^{\mathrm{deC}}$ & $17.9 \pm 0.36^{\mathrm{gD}}$ \\
\hline & \multirow{3}{*}{ WY } & 15 & $11.3 \pm 0.68^{\mathrm{dA}}$ & $13.4 \pm 0.41^{\mathrm{dB}}$ & $14.0 \pm 0.42^{\mathrm{dC}}$ & $14.2 \pm 0.38^{\mathrm{cdC}}$ \\
\hline & & 20 & $12.9 \pm 0.42^{\mathrm{faA}}$ & $13.1 \pm 0.12^{\mathrm{deA}}$ & $14.2 \pm 0.52^{\mathrm{deB}}$ & $16.5 \pm 0.41^{\mathrm{fC}}$ \\
\hline & & 25 & $12.0 \pm 0.38^{\mathrm{eA}}$ & $12.9 \pm 0.35^{\mathrm{eB}}$ & $14.5 \pm 0.18^{\mathrm{deC}}$ & $18.2 \pm 0.53^{\mathrm{fgC}}$ \\
\hline
\end{tabular}

${ }^{*} \mathrm{C}$ : control sprouts, Y: sprouts elicited by yeast, W: sprouts elicited by willow, and WY: sprouts elicited by willow/yeast mixture.

${ }^{* *}$ The values designated by the different small letters in the columns of the table and the values designated by the different capital letters in the lines of the table are significantly different $(a=0.05)$.

of germination time increased, resulting in the increase in total phenolic compound and antioxidant activity of the sprouted wheat flour. There was an increase in TPC and the antioxidant activity of the alcoholic extracts in wheat flour as the germination time was extended. In the case of legumes sprouting usually results in a reduction in the TPC [26]. Limón et al. [11] found that elicitation of kidney beans improves the health-promoting potential of sprouts and allows us to obtain ingredients which might reduce oxidative stress and hypertension.
The total phenolics content (TPC) in relation to germination temperature (GT) and germination time (GD) for all tested samples of sprouts can be described by the following equation:

$$
\begin{aligned}
\mathrm{TPC}= & -0,0553 \mathrm{GT}^{2}+2,274 \mathrm{GT}+0,7865 \mathrm{GD} \\
& -12,124 ; \quad R^{2}=0,701 .
\end{aligned}
$$

The values of antioxidant activity (AA) in sprouts before germination were 7.52, 8.12, and 7.85\% for Bogatka, Mulan, 
TABLE 2: The range of microbial load (cfu/g) on sprouts in relation to germination temperature and germination time.

\begin{tabular}{|c|c|c|c|c|c|c|}
\hline \multirow{2}{*}{ Cultivar } & \multirow{2}{*}{$\mathrm{GT},{ }^{\circ} \mathrm{C}$} & \multirow{2}{*}{ TM } & \multicolumn{4}{|c|}{ Germination time (days) } \\
\hline & & & 2 & 4 & 6 & 8 \\
\hline \multirow{3}{*}{ Bogatka } & 15 & & $5.0 \cdot 10^{3}-3.5 \cdot 10^{4}$ & $5.9 \cdot 10^{4}-8.8 \cdot 10^{4}$ & $3.5 \cdot 10^{5}-9.5 \cdot 10^{5}$ & $6.8 \cdot 10^{5}-9.8 \cdot 10^{5}$ \\
\hline & 20 & & $6.2 \cdot 10^{4}-7.3 \cdot 10^{4}$ & $7.1 \cdot 10^{4}-9.9 \cdot 10^{4}$ & $1.2 \cdot 10^{5}-1.5 \cdot 10^{6}$ & $1.4 \cdot 10^{6}-3.8 \cdot 10^{6}$ \\
\hline & 25 & & $6.6 \cdot 10^{5}-8.5 \cdot 10^{5}$ & $7.8 \cdot 10^{5}-3.5 \cdot 10^{6}$ & $1.3 \cdot 10^{6}-3.8 \cdot 10^{7}$ & $1.2 \cdot 10^{7}-2.9 \cdot 10^{7}$ \\
\hline \multirow{3}{*}{ Mulan } & 15 & & $4.3 \cdot 10^{3}-8.5 \cdot 10^{3}$ & $9.1 \cdot 10^{3}-2.1 \cdot 10^{4}$ & $1.5 \cdot 10^{4}-4.2 \cdot 10^{5}$ & $2.8 \cdot 10^{5}-6.8 \cdot 10^{5}$ \\
\hline & 20 & Aerobic bacteria & $5.4 \cdot 10^{4}-6.3 \cdot 10^{4}$ & $2.1 \cdot 10^{5}-4.2 \cdot 10^{5}$ & $3.2 \cdot 10^{5}-6.5 \cdot 10^{6}$ & $8.8 \cdot 10^{5}-2.8 \cdot 10^{6}$ \\
\hline & 25 & & $6.2 \cdot 10^{5}-7.3 \cdot 10^{5}$ & $3.1 \cdot 10^{6}-8.8 \cdot 10^{6}$ & $7.3 \cdot 10^{6}-8.8 \cdot 10^{7}$ & $6.2 \cdot 10^{7}-9.9 \cdot 10^{7}$ \\
\hline \multirow{3}{*}{ Muszelka } & 15 & & $1.1 \cdot 10^{3}-2.8 \cdot 10^{4}$ & $3.5 \cdot 10^{3}-1.1 \cdot 10^{4}$ & $8.5 \cdot 10^{4}-1.5 \cdot 10^{5}$ & $3.8 \cdot 10^{5}-6.2 \cdot 10^{5}$ \\
\hline & 20 & & $6.2 \cdot 10^{3}-2.1 \cdot 10^{4}$ & $2.1 \cdot 10^{4}-3.9 \cdot 10^{4}$ & $7.2 \cdot 10^{4}-9.5 \cdot 10^{5}$ & $6.4 \cdot 10^{5}-1.4 \cdot 10^{6}$ \\
\hline & 25 & & $4.9 \cdot 10^{4}-6.5 \cdot 10^{5}$ & $9.4 \cdot 10^{5}-1.2 \cdot 10^{6}$ & $1.6 \cdot 10^{6}-2.4 \cdot 10^{7}$ & $1.4 \cdot 10^{7}-3.9 \cdot 10^{7}$ \\
\hline \multirow{3}{*}{ Bogatka } & 15 & & nd & nd & nd & $5.0 \cdot 10^{1}-1.0 \cdot 10^{2}$ \\
\hline & 20 & & nd & nd & $6.2 \cdot 10^{1}-5.0 \cdot 10^{2}$ & $3.2 \cdot 10^{2}-6.1 \cdot 10^{3}$ \\
\hline & 25 & & nd & $3.5 \cdot 10^{1}-1.3 \cdot 10^{2}$ & $6.2 \cdot 10^{2}-9.5 \cdot 10^{2}$ & $9.2 \cdot 10^{2}-4.5 \cdot 10^{3}$ \\
\hline \multirow{3}{*}{ Mulan } & 15 & & nd & nd & nd & nd \\
\hline & 20 & Molds & nd & nd & $1.1 \cdot 10^{1}-9.1 \cdot 10^{1}$ & $2.0 \cdot 10^{1}-5.1 \cdot 10^{2}$ \\
\hline & 25 & & nd & $2.3 \cdot 10^{1}-6.5 \cdot 10^{2}$ & $9.2 \cdot 10^{2}-1.5 \cdot 10^{3}$ & $2.7 \cdot 10^{3}-6.8 \cdot 10^{4}$ \\
\hline \multirow{3}{*}{ Muszelka } & 15 & & nd & nd & nd & $2.0 \cdot 10^{1}-3.3 \cdot 10^{1}$ \\
\hline & 20 & & nd & nd & $1.0 \cdot 10^{1}-2.3 \cdot 10^{1}$ & $7.4 \cdot 10^{1}-8.8 \cdot 10^{1}$ \\
\hline & 25 & & nd & nd & $1.8 \cdot 10^{1}-2.6 \cdot 10^{2}$ & $3.3 \cdot 10^{2}-7.7 \cdot 10^{3}$ \\
\hline
\end{tabular}

${ }^{*}$ GT: germination temperature, TM: type of microorganism, and nd: not detected.

and Muszelka, respectively. The AA for both elicited and control sprouts increased as the time of germination increased (average from 10.6 to $15.1 \%$ ). This tendency was observed for each cultivar and for each temperature of seeds germination (Table 1). Generally the increase of germination temperature caused an increase in AA. However the values of AA obtained for sprouts germinated at $20^{\circ} \mathrm{C}$ and $25^{\circ} \mathrm{C}$ were similar and in the most cases significantly higher than the values of AA obtained for sprouts germinated at $15^{\circ} \mathrm{C}$. Elicitation of wheat seeds by yeast extract had generally no significant influence on AA of spouts, whereas elicitors from bark and mixture of bark with yeast caused significant increase AA, especially for seeds germinated at $20^{\circ} \mathrm{C}$. The average value of AA for sprouts without elicitation was $11.7 \%$, whereas for elicited seeds the values of AA were 12.0, 13.9, and 13.6\% for seeds elicited by yeast, bark, and their mixture, respectively. A previous study proved that $S$. daphnoides water extract was an effective elicitor for improving antioxidant potential of broccoli sprouts [24]. Generally a similar level of AA was obtained for individual wheat cultivars. The lowest values of AA were obtained for sprouts obtained from Bogatka cv. (average 12.2\%) and the highest for Mulan (13.1\%). The AA of wheat sprouts significantly and positively correlated with TPC (Figure 4).

The results of the microbiological analysis of sprouted flour samples are shown in Table 2. For all samples, the aerobic bacteria counts in germinated wheat seed flour ranged between $1.1 \cdot 10^{3}$ and $6.2 \cdot 10^{7} \mathrm{cfu} / \mathrm{g}$ and increased as the germination time and germination temperature increased. However only in the case of sprouts germinated at 15 and $20^{\circ} \mathrm{C}$ and up to 4 days the levels of aerobic bacteria did not exceed the usually accepted limits [28].

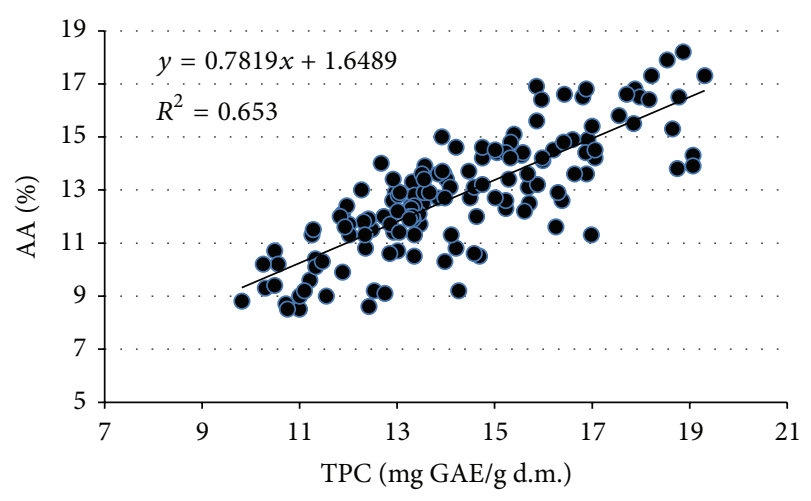

FIGURE 4: The relation between antioxidant activity (AA) and total phenolics content (TPC) in wheat sprouts.

Generally in grains germinated at lower temperature $\left(15^{\circ} \mathrm{C}\right.$ and $\left.20^{\circ} \mathrm{C}\right)$ and during 2 and 4 days the molds were not detected. For sprouted flour obtained from Bogatka and germinated at $15^{\circ} \mathrm{C}$ the molds counts were not detected during the entire period of germination. A similar situation was observed for sprouted flour obtained from Muszelka and Mulan and germinated for 6 days at $15^{\circ} \mathrm{C}$. For other samples the mean molds counts ranged from $1.0 \cdot 10^{1}$ to $9.2 \cdot 10^{3} \mathrm{cfu} / \mathrm{g}$ but did not exceed the overall acceptable limits of molds [28]. Both higher temperature and high water activity during germination resulted in the fact that the highest values of molds were obtained for sprouted flour germinated at $25^{\circ} \mathrm{C}$ and for 8 days, whereas Salmonella spp., E. coli, and yeasts were not detected in any of the sprouted flour samples. It is worth noting that the higher microbiological contamination 
of sprouts can influence the TPC content. Thus, the results concerning TPC and/or antioxidant activity of sprouts may be overestimated. Therefore the microbiological purity of sprouts should be always determined.

The microflora of flour is composed of a variety of microorganisms and depends on the bacteria on the grains. Flour is generally regarded as a microbiologically safe product as it is a low water activity commodity. Australian, European, and US studies indicate that Salmonella spp., Escherichia coli, Bacillus cereus, and other spoilage microorganisms are present in wheat and flour at low levels [28, 29].

\section{Conclusions}

Results here obtained indicate that germination conditions significantly influenced biological activity of wheat sprouts. The increase of germination time caused an increase of the TPC and AA for all samples. However, the germination temperature slightly influenced these indices. Generally the highest values in TPC and AA were found for sprouts germinated at $20^{\circ} \mathrm{C}$. Similar values of these parameters were obtained for all tested cultivars.

Besides, this study demonstrated that elicitation practices can significantly affect the nutritional quality of treated wheat and may be a cost-effective tool to enhance the healthfulness of wheat sprouts. Especially the values of TPC and AA obtained for sprouts elicited by bark extract were in the most cases significantly higher than the values received for control sample.

The results of microbiological examination showed that, generally for seeds germinated at lower temperature $\left(15^{\circ} \mathrm{C}\right.$ and $20^{\circ} \mathrm{C}$ ) and during 2 and 4 days, the molds were not detected and the levels of aerobic bacteria did not exceed the usually accepted limits. The highest levels microbiological contamination were obtained for wheat sprouts germinated at $25^{\circ} \mathrm{C}$ and for 8 days.

Taking into account both biological activity and microbiological purity of samples the best quality sprouts were in the most cases obtained for wheat germinated during four days at $20^{\circ} \mathrm{C}$ and elicited by $S$. daphnoides bark extract.

\section{Conflict of Interests}

The authors declare that there is no conflict of interests regarding the publication of this paper.

\section{Acknowledgment}

The study was financed by the Polish National Science Centre (Grant 2012/07/B/NZ9/02463).

\section{References}

[1] P. R. Shewry, G. Charmet, G. Branlard et al., "Developing new types of wheat with enhanced health benefits," Trends in Food Science \& Technology, vol. 25, no. 2, pp. 70-77, 2012.

[2] D. Nigro, S. L. Giove, S. Fortunato et al., "Allelic variation of wheat flour allergens in a collection of wheat genotypes," Journal of Chemistry, vol. 2014, Article ID 629379, 7 pages, 2014.
[3] P. V. Hung, D. W. Hatcher, and W. Barker, "Phenolic acid composition of sprouted wheats by ultra-performance liquid chromatography (UPLC) and their antioxidant activities," Food Chemistry, vol. 126, no. 4, pp. 1896-1901, 2011.

[4] P. Koehler, G. Hartmann, H. Wieser, and M. Rychlik, "Changes of folates, dietary fiber, and proteins in wheat as affected by germination," Journal of Agricultural and Food Chemistry, vol. 55, no. 12, pp. 4678-4683, 2007.

[5] R. Fernandez-Orozco, J. Frias, H. Zielinski, M. K. Piskula, H. Kozlowska, and C. Vidal-Valverde, "Kinetic study of the antioxidant compounds and antioxidant capacity during germination of Vigna radiata cv. emmerald, Glycine max cv. jutro and Glycine max cv. merit," Food Chemistry, vol. 111, no. 3, pp. 622-630, 2008.

[6] H. Y. Kim, I. G. Hwang, T. M. Kim et al., "Chemical and functional components in different parts of rough rice (Oryza sativa L.) before and after germination," Food Chemistry, vol. 134, no. 1, pp. 288-293, 2012.

[7] D. Dziki, R. Różyło, U. Gawlik-Dziki, and M. Świeca, "Current trends in the enhancement of antioxidant activity of wheat bread by the addition of plant materials rich in phenolic compounds," Trends in Food Science \& Technology, vol. 40, no. 1, pp. 48-61, 2014.

[8] K. Lorenz and R. Valvano, "Functional characteristics of sproutdamaged soft white wheat flours," Journal of Food Science, vol. 46, no. 4, pp. 1018-1020, 1981.

[9] K. S. Sekhon, N. Singh, H. Kaur, and H. P. S. Nagi, "Improving the functional and bread making properties of sprouted Indian wheat," Journal of Food Processing and Preservation, vol. 19, no. 2, pp. 147-160, 1995.

[10] S. P. Shingare and B. N. Thorat, "Fluidized bed drying of sprouted wheat (Triticum aestivum)," International Journal of Food Engineering, vol. 10, no. 1, pp. 29-37, 2013.

[11] R. I. Limón, E. Peñas, C. Martínez-Villaluenga, and J. Frias, "Role of elicitation on the health-promoting properties of kidney bean sprouts," LWT-Food Science and Technology, vol. 56, no. 2, pp. 328-334, 2014.

[12] M. Świeca, Ł. Sęczyk, and U. Gawlik-Dziki, "Elicitation and precursor feeding as tools for the improvement of the phenolic content and antioxidant activity of lentil sprouts," Food Chemistry, vol. 161, pp. 288-295, 2014.

[13] E. Burguieres, P. McCue, Y.-I. Kwon, and K. Shetty, "Effect of vitamin $\mathrm{C}$ and folic acid on seed vigour response and phenoliclinked antioxidant activity," Bioresource Technology, vol. 98, no. 7, pp. 1393-1404, 2007.

[14] U. Gawlik-Dziki, M. Świeca, D. Dziki, and D. Sugier, "Improvement of nutraceutical value of broccoli sprouts by natural elicitors," Acta Scientiarum Polonorum, Hortorum Cultus, vol. 12, no. 1, pp. 129-140, 2013.

[15] S. Pérez-Balibrea, D. A. Moreno, and C. García-Viguera, "Improving the phytochemical composition of broccoli sprouts by elicitation," Food Chemistry, vol. 129, no. 1, pp. 35-44, 2011.

[16] D. Dziki and J. Laskowski, "Study to analyze the influence of sprouting of the wheat grain on the grinding process," Journal of Food Engineering, vol. 96, no. 4, pp. 562-567, 2010.

[17] R. Re, N. Pellegrini, A. Proteggente, A. Pannala, M. Yang, and C. Rice-Evans, "Antioxidant activity applying an improved ABTS radical cation decolorization assay," Free Radical Biology and Medicine, vol. 26, no. 9-10, pp. 1231-1237, 1999.

[18] V. L. Singleton and A. Rossi, "Colorimetry of total phenolics with phosphomolybdic-phosphotungstics acid reagents," American Journal of Enology and Viticulture, vol. 16, no. 3, pp. 144-158, 1965. 
[19] PN-EN ISO 4833, "Microbiology of food and animal feeding stuffs-horizontal method for the enumeration of microorganisms," 2004.

[20] ISO, "Microbiology of food and animal feeding stuffs-horizontal method for the enumeration of yeasts and molds," Tech. Rep. PN-ISO-21527-2, ISO, 2009.

[21] PN-ISO 4832, "Microbiology of food and animal feeding stuffs-horizontal method for the enumeration of coliformscolony-count technique," 2007.

[22] PN-EN ISO 6579, "Microbiology of food and animal feeding stuffs-horizontal method for the detection of Salmonella spp.", 2003.

[23] H. Nonogaki, G. W. Bassel, and J. D. Bewley, "Germination-still a mystery," Plant Science, vol. 179, no. 6, pp. 574-581, 2010.

[24] U. Gawlik-Dziki, M. Świeca, and D. Sugier, "Enhancement of antioxidant abilities and the lipoxygenase and xanthine oxidase inhibitory activity of broccoli sprouts by biotic elicitors," Acta Scientiarum Polonorum, Hortorum Cultus, vol. 11, no. 1, pp. 1325, 2012.

[25] M. T. Huang, C. T. Ho, and C. Y. Lee, Phenolic Compounds in Food and Their Effects on Health II: Antioxidants and Cancer Prevention, vol. 507 of American Chemical Society Symposium Series, American Chemical Society, Washington, DC, USA, 1992.

[26] M. Świeca, U. Gawlik-Dziki, D. Kowalczyk, and U. Złotek, "Impact of germination time and type of illumination on the antioxidant compounds and antioxidant capacity of Lens culinaris sprouts," Scientia Horticulturae, vol. 140, pp. 87-95, 2012.

[27] F. Yang, T. K. Basu, and B. Ooraikul, "Studies on germination conditions and antioxidant contents of wheat grain," International Journal of Food Sciences and Nutrition, vol. 52, no. 4, pp. 319-330, 2001.

[28] A. Aydin, P. Peter, and F. J. M. Smulders, "The physico-chemical and microbiological properties of wheat flour in Thrace," Turkish Journal of Agriculture \& Forestry, vol. 33, no. 5, pp. 445454, 2009.

[29] K. S. Richter, E. Dorneanu, K. M. Eskridge, and C. S. Rao, "Microbiological quality of flours," Cereal Food World, vol. 38, pp. 367-369, 1993. 

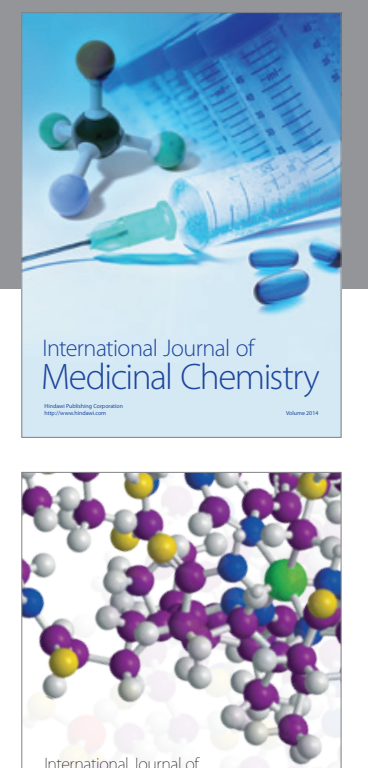

\section{Carbohydrate} Chemistry

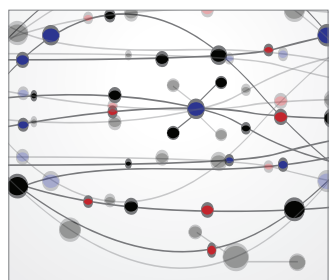

The Scientific World Journal
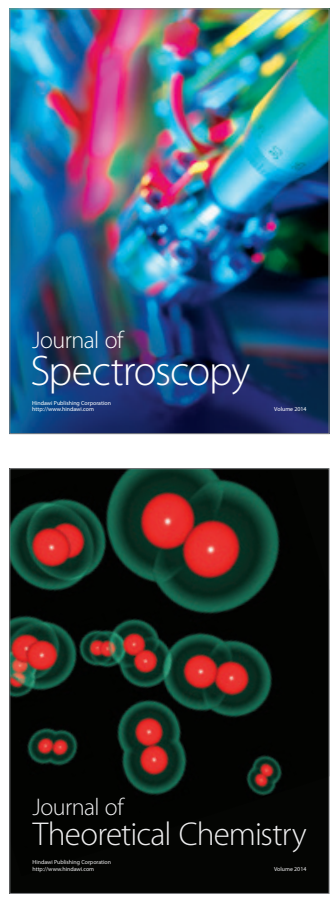
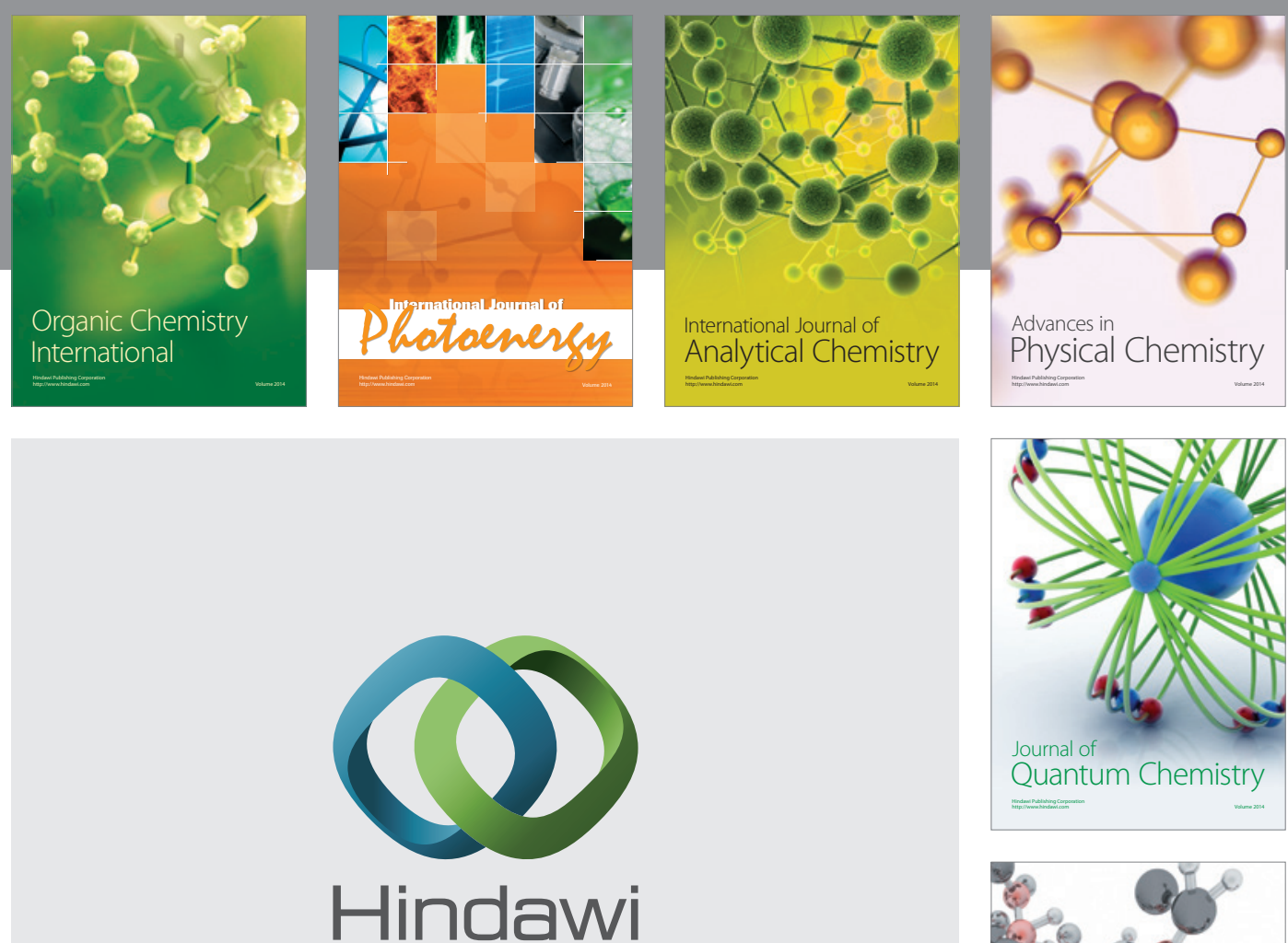

Submit your manuscripts at

http://www.hindawi.com

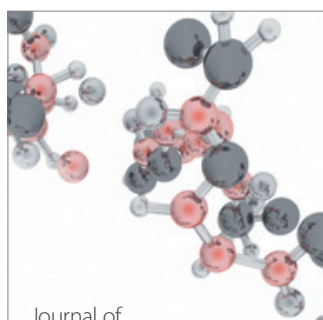

Analytical Methods

in Chemistry

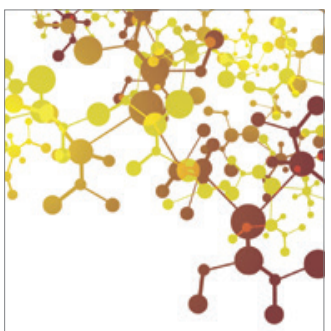

Journal of

Applied Chemistry

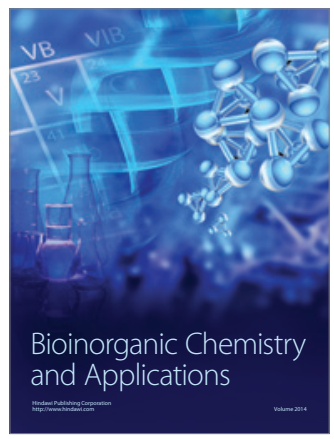

Inorganic Chemistry
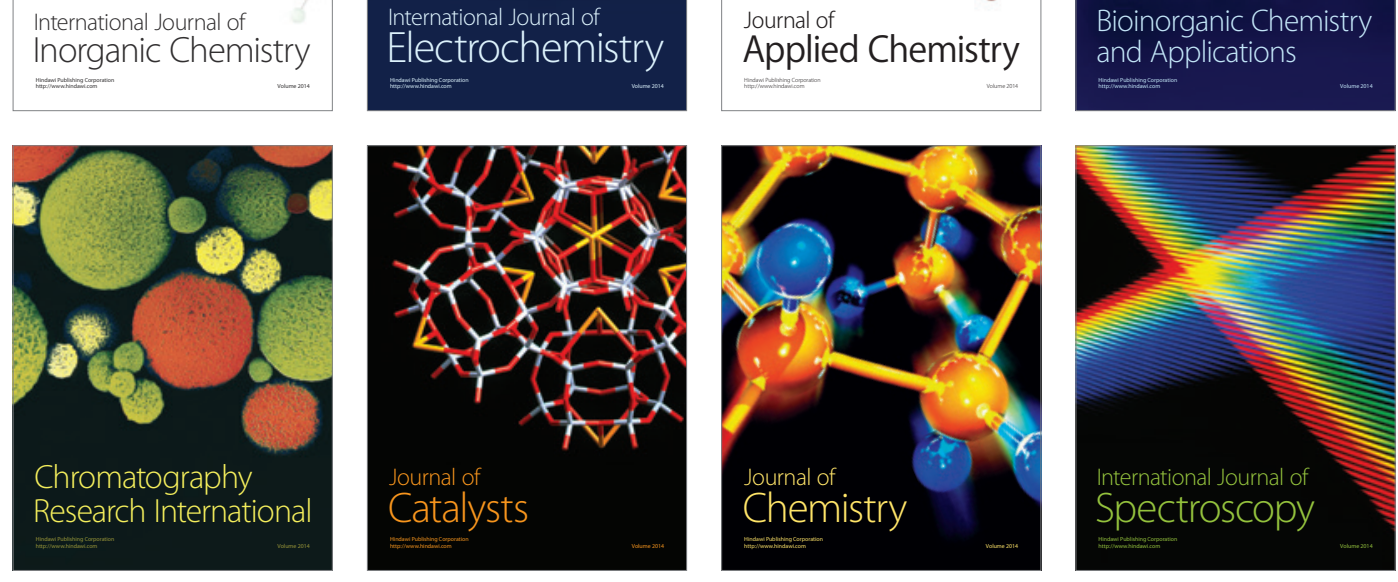